\title{
DEVELOPING REFLECTIVE PRIMARY TEACHERS: TALKING SCIENCE AND SPEAKING ENGLISH AS AN ADDITIONAL LANGUAGE
}

\author{
FORMANDO PROFESSORES DO ENSINO FUNDAMENTAL REFLEXIVOS: \\ CONVERSANDO SOBRE CIÊNCIAS E FALANDO INGLÊS COMO UMA LÍNGUA ADICIONAL
}

\author{
FORMANDO MAESTROS DE PRIMÁRIA REFLEXIVOS: \\ HABLANDO CIENCIA E CHARLANDO INGLÉS COMO UNA LENGUA ALTERNATIVA
}

\author{
Gloria Jové Monclus ${ }^{1}$ \\ Charly Ryan ${ }^{2}$ \\ Esther Betrián Villas ${ }^{3}$ \\ Mireia Farrero Oliva ${ }^{4}$
}

\begin{abstract}
In this article we present a case study in initial education of teachers studying the Primary Education Degree of the University of Lleida. Students prepare a teaching plan for science content linked to community resources, and present it in English. The aim was the students experience "talking science" in English. We focus on the questions: What have we experienced doing this activity in English? Students refer to impotence and frustration at expressing themselves and their ideas in English. While the data shows that there was little focus on science content, they showed the value of the exercise in their development as teachers. They experience 'otherness' and connect this to their future roles as teachers in multi-lingual, multi-cultural classrooms. Preparing this case study shows the value of teacher educators reflecting on their practice.
\end{abstract}

KEYWORDS: Talking science. Speaking English. Initial education of teachers. Experience. Transdisciplinarity. Reflective practice. Otherness.

RESUMO: Neste artigo, apresentamos um estudo de caso em formação inicial de professores do curso de Pedagogia da Universidade de Lleida. Os estudantes preparam uma programação didática para um conteúdo de ciências vinculado a recursos comunitários. A proposta é desenvolvida em inglês. O objetivo é que os estudantes experienciem "falar ciência" em inglês. Centramo-nos na pergunta: O que experienciamos fazendo esta atividade em inglês. Os estudantes fazem referência à impotência e à frustração que lhes causa expressar suas ideias em Inglês. Enquanto os dados nos mostram que os estudantes centram pouca atenção no conteúdo de Ciências, eles apontam o valor deste exercício para seu desenvolvimento docente. Vivem a "alteridade" e a associam com seu futuro papel como professores em classes multilinguísticas e multiculturais. Também nos mostram o valor de refletir sobre a própria prática na formação de professores.

\footnotetext{
${ }^{1}$ Professora do Departamento de Pedagogía y Psicología da Universidad de Lleida. E-mail: gjove@pip.udl.cat.

${ }^{2}$ Professor da Faculty of Education, Health and Social Care, University of Winchester. E-mail: charly.Ryan@winchester.ac.uk.

${ }^{3}$ Professora do Departamento de Pedagogía y Psicología da Universidad de Lleida. E-mail: estherbetrian@pip.udl.cat.

${ }^{4}$ Professora do Departamento de Pedagogía y Psicología da Universidad de Lleida. E-mail: mireiafarrero@pip.udl.cat.

Recebido em: 30/05/2015 - Aprovado em: 22/07/2015.
} 
PALAVRAS-CHAVE: Falar ciência. Falar inglês. Formação inicial de professore. Experiência. Transdisciplinaridade. Prática reflexiva. Alteridade.

RESUMEN: En este artículo presentamos un caso de estudio en Formación de Maestros del Grado de Educación Primaria de la Universidad de Lleida. Los estudiantes preparan una programación didáctica para un contenido de ciencias que vinculan a un recurso comunitario. La propuesta se lleva a cabo en Inglés. El objetivo es que los estudiantes experiencien "hablar ciencia" en Inglés. Nos centramos en la pregunta: ¿Qué hemos experienciado haciendo esta actividad en Inglés? Los estudiantes hacen referencia a la impotencia y la frustración que les genera expresar sus ideas en Inglés. Mientras los datos nos muestran que se centran poco en el contenido de ciencias, ellos muestran el valor de este ejercicio para su desarrollo como docentes. Viven la "alteridad" y la vinculan a su futuro papel como docentes en aulas multilingües y multiculturales. También mostramos el valor y la importancia de reflexionar sobre la propia práctica en formación de maestros.

PALABRAS-CLAVE: Hablar ciência. Ablar inglês. Formación incial de maestros. Experiencia. Transdisciplinaridad. Practica reflexiva. Alteridad.

\section{INTRODUCTION}

Over the last decade in Spain, the policy of the relevant educational authorities has been to support projects of Content Language Integrated Learning CLIL (Euryce, 2006; Lasagabaster and Ruiz de Zarobe, 2010; Naves and Victori, 2010), and specifically in Catalonia, Content and Foreign Language Integrated Learning (AICLEm for English and EMILE, for French). Content and Foreign Language Integrated Learning (AICLEm and CLIL) is a branch of applied linguistics that argues for a greater success in learning foreign languages at school when these are used to teach core subjects like history or science, than when they are taught separately. This approach claims that it is not only for teaching of new content in a language other than the students' first language, but also for skills, cognitive styles, learning rhythms and different cultures, among others, which are essential when educating multilingual people for society in the twenty-first century. In this paper we present a case study in initial teacher education in the Primary Education Degree at the University of Lleida, Spain. The aim of was to live and have the experience of "talking science" in a foreign language, specifically English. This case study will focus not only on the CLIL context, but its impact on future schoolteachers' thinking and reflection on these possible practices through their experience of working in another language.

The term Content Language Integrated Learning (CLIL) (Coyle, 2006; Mehisto, Marsh and Frigols, 2008) is used to describe any educational situation in which learning and teaching of curricular content is through an additional language, that is, a language that is not present in the students' immediate surroundings. This connects to the educational practices of integrated content and language learning (Escobar \& Nusbaum, 2011). Currently, the term CLIL includes several educational approaches as well as synthesizing and providing a flexible way to apply the knowledge learned. Thus, as these authors claim, Catalonia's immersion programmes were based on "avant la lettre" perspectives, because they simultaneously sought to encourage learning of Catalan and curricular contents. 
For Coyle (2007) the concept of integrated language and curricular contents is essential when understanding CLIL as he claims this integration promotes content learning as well as foreign language of learning (Coyle, 2007). He argues for more research into experiences and case studies in CLIL contexts and we offer our case in response.

In Spain, schools have full autonomy to initiate such language projects provided they have sufficient human resources and the teachers who develop it have a B2 level of the target language (Council of Europe 2011). The school decides on which curriculum areas and at what ages or stages it will be applied, and then plans progressive implementation and assessment processes.

In most primary schools it is implemented in areas like Environmental Awareness, in science and arts education. Training in the field of CLIL methodology, exchange of experiences between schools and monitoring of training needs, as well as guidance for the development of the process and analysis of results are provided by local authorities.

\section{WHAT DOES "TALKING SCIENCE" MEAN?}

Language, as it is used in science classes, plays a key role in the learning taking place. Studies by Fensham (2008) and Lemke (1990) have demonstrated how the use of impersonal and formal language unrelated to students' experiences and reality does not help them to learn. When students are able to debate, discuss, speak and write about science the understanding of scientific ideas is encouraged (UNESCO, 2010). and when the aim of science classes is for students to gain a personal understanding and develop their own thoughts, that is, when reasoning is necessary, it is better to use the language with which they feel more comfortable. According to Camaño (2010: 6):

"Reasoning is not a luxury in scientific education, but an absolutely essential process to understand the concepts and theories and the nature of science, thus becoming a powerful strategy for teaching and learning science."

According to Hodson (2009) activities based on language used in science class have to enable students to explore, develop, expand, and rearrange their own thoughts and their ability to build scientific arguments. Thus language changes from a teaching to a learning tool and a strategy for developing thinking, ideas and concepts.

However, what happens when we need to argue using a language with which we are less familiar? Research by Johnstone and Selepeng (2001) has shown that in countries where science is taught using foreign languages, it is more difficult to debate, discuss, speak and write about science. That means it is more difficult to develop meaningful learning because people's "mental work spaces" become reduced when working in unfamiliar languages. 
Investigations of universities teaching in a second language yield similar results (Wilkins \& Urbanovič 2014)

\section{OUR PROJECT}

Our project is set in the Primary Education Degree subject "Educational Processes and Contexts". This is a core subject in the second year of a four year teacher education programme. The basic aim arises from a key question posed to future schoolteachers: 'How can I build and rebuild myself as a learner to become a teacher?' Through the activities, the models we have seen as school students and those we are seeing as university students and future schoolteachers emerge. We are becoming aware of them. This enables us to question our beliefs, strategies, actions and attitudes about what learning and teaching means. To stimulate these developments, we attempt to rupture transmission models of teaching and learning by starting in contemporary art exhibitions rather than a university classroom. From these experiences with contemporary art, students make connections to their schooling, to learning and teaching, and to educational texts such as those by Morin (2008). This leads to work from a transdisciplinary perspective, exploring the benefits of working beyond the classroom with community resources (Jové and Betrián, 2012).

During the 2011-2012 academic year, the initial learning context was a piece $L a$ Calaixera [Chest of drawers] by Curro Claret and works by Lara Almarcegui Basurama, which all address the theme of the 3Rs (Reduce, Reuse and Recycle) from different perspectives. The 225 students enrolled in the subject were organized into groups of 4 or 5 members. They chose an area they wanted to study further in order to develop a project to use in school. The aim of the exercise was to share, think about and delve deeper into their knowledge of science and their own learning as becoming teachers. Topics such as "Let's give life to our rubbish", "The Three Rs in our daily life" and "The depletion of water" evolved from our students' self-management and decision-making. Throughout the course they worked under the supervision of the teaching team. The groups presented their work publicly in English during the first half of May, coinciding with the presence of the visiting professor from Winchester, UK, in the context of the programme of internalization of undergraduate studies. Our goal was to create and share the knowledge built within the class group, with the teaching staff of Educational Processes and Contexts and a professor of science education from the University of Winchester. Students presented their ideas in English and ended their interventions by posing questions so everybody could continue learning through interaction and the community created in English. Finally, we held a joint extra debriefing session outside the classroom, in an area of the campus, in which some one hundred students participated.

For this debriefing session we used Nominal group Technique (Delbecq, Van de Ven and Gustafson 1975). Students had to bring a reflection about their own learning process based on the following questions: 
1 - What have I learned as a person?

2 - What have I learned as a future schoolteacher?

3 - What have I learned as a member of a community?

4 - What could I have done to learn more while carrying out the activity?

5 - What could the teachers have done for us to learn more?

6 - What could my colleagues have done to learn more?

7 - What has doing this activity in English meant to us and what have we experienced?

The $10^{\text {th }}$ of May came and we went outside to the "little hill on the campus" [La Montañeta]. To be coherent with the theme of the three Rs, we reused materials and coloured stickers. The students were divided into four groups "the size of a tree's shadow", and then asked to individually write on self-adhesive slips of paper, "Post-its", the phrases, thoughts and knowledge in response to each of the seven questions given above. Each of the groups collected together replies to Question 1 on one poster, to question 2 on a second poster, and so on. The students were then asked to read all the answers to each question and then rank them according to the ones they agreed with most. Once the ideas were organized, each student was given different-coloured stickers to rank their thoughts in accordance with their degree of agreement; from more agreement to less. The students placed their stickers on each "Post-it" according to how much they agreed with what their classmates had written, as shown in Table 1.

Table 1 - Ranking of responses by Group 1 to question 7 What has doing this activity in English meant to us and what have we experienced?

\begin{tabular}{|c|c|c|c|c|c|}
\hline \multirow[t]{2}{*}{ Sentences } & \multicolumn{5}{|c|}{ Preference Order } \\
\hline & $\begin{array}{l}\text { High } \\
1\end{array}$ & 2 & 3 & 4 & $\begin{array}{l}\text { Low } \\
5\end{array}$ \\
\hline Uncertainty, frustration and lack of confidence in myself & 7 & 1 & 1 & 3 & 0 \\
\hline Helplessness of not knowing and mastering the language & 3 & 0 & 1 & 3 & 0 \\
\hline $\begin{array}{l}\text { For me this experience has been very rewarding because within } \\
\text { a few months I go from Erasmus and I was able to experience } \\
\text { before I go how I feel. It has helped me to realize that we have } \\
\text { to overcome obstacles such as English and you must learn to } \\
\text { enjoy it. }\end{array}$ & 3 & 0 & 0 & 0 & 1 \\
\hline $\begin{array}{l}\text { I have experienced that everything is possible with effort and } \\
\text { persistence }\end{array}$ & 2 & 2 & 1 & 1 & 0 \\
\hline $\begin{array}{l}\text { I have experienced uncertainty and insecurity during the } \\
\text { presentation because it was a new experience because I had } \\
\text { trouble because the resources we had were very few }\end{array}$ & 1 & 6 & 4 & 0 & 0 \\
\hline Communicate with a native & 1 & 0 & 0 & 1 & 0 \\
\hline $\begin{array}{l}\text { I have experienced that the level of English is low, but we can } \\
\text { understand. }\end{array}$ & 0 & 3 & 1 & 1 & 1 \\
\hline $\begin{array}{l}\text { Over time I realized that I understood more than I thought. We } \\
\text { could understand, discuss and learn through dialogue. }\end{array}$ & 0 & 2 & 1 & 2 & 0 \\
\hline Uncertainty and ridiculous & 0 & 1 & 2 & 0 & 2 \\
\hline Reality of knowledge of English among students & 0 & 1 & 0 & 0 & 1 \\
\hline
\end{tabular}


We then discussed the outcomes with the students; we recorded the discussion for later analysis. A Wiki was set up as an additional resource for thinking. Students were invited to write comments on what the activity had entailed and on their experience; 44 students participated. The following week the students handed in their written assignments including the contributions from the sessions and the links they made with the other projects presented.

\section{RESULTS AND DISCUSSION}

All of the assignments and contributions from the debriefing session were subject to qualitative data analysis strategies. In this article we present those referring to learning in English and Question 7 - What has doing this activity in English meant to us and what have we experienced? As an example we include Table 1 with the results obtained in Group 1 to show the extent of their contributions. Where participants agreed, they merged their comments. This gave twenty one different responses. To simplify presentation, Table 1 includes only the top 10 ranked items. Table 2 shows the leading items from the four groups' rankings in their response to Question 7.

Table 2 - Highest ranked contributions from the four groups

\begin{tabular}{|l|c|c|c|c|c|}
\hline Sentences & \multicolumn{5}{|c|}{ Preference order } \\
\cline { 2 - 6 } & $\begin{array}{c}\text { High } \\
1\end{array}$ & 2 & 3 & 4 & $\begin{array}{c}\text { Low } \\
5\end{array}$ \\
\hline $\begin{array}{l}\text { Powerlessness and frustration over } \\
\text { wanting to express myself and not } \\
\text { knowing how }\end{array}$ & 12 & 1 & 5 & 3 & 0 \\
\hline $\begin{array}{l}\text { We were put in the role of newly arrived } \\
\text { students }\end{array}$ & 7 & 2 & 0 & 0 & 0 \\
\hline $\begin{array}{l}\text { Uncertainty, frustration and lack of } \\
\text { confidence in myself }\end{array}$ & 7 & 1 & 1 & 3 & 0 \\
\hline $\begin{array}{l}\text { A challenge for personal growth. I have } \\
\text { learned that every effort has its reward }\end{array}$ & 7 & 0 & 0 & 0 & 1 \\
\hline $\begin{array}{l}\text { I have identified the issue of overcoming } \\
\text { language difficulties }\end{array}$ & 3 & 0 & 1 & 0 & 0 \\
\hline
\end{tabular}

The responses to the Nominal Group Technique questions were analysed for word frequency. Fig 1 shows the Reponses to question 7, about working in English, in the form of a Wordle (Wordle.net); larger font represents higher frequency Figure 2 shows the word frequency analysis for the Wiki and Figure 3 that from the written assignments. 
Figure 1 - Word frequency diagram from the four groups of students about the experience of presenting their science in English.

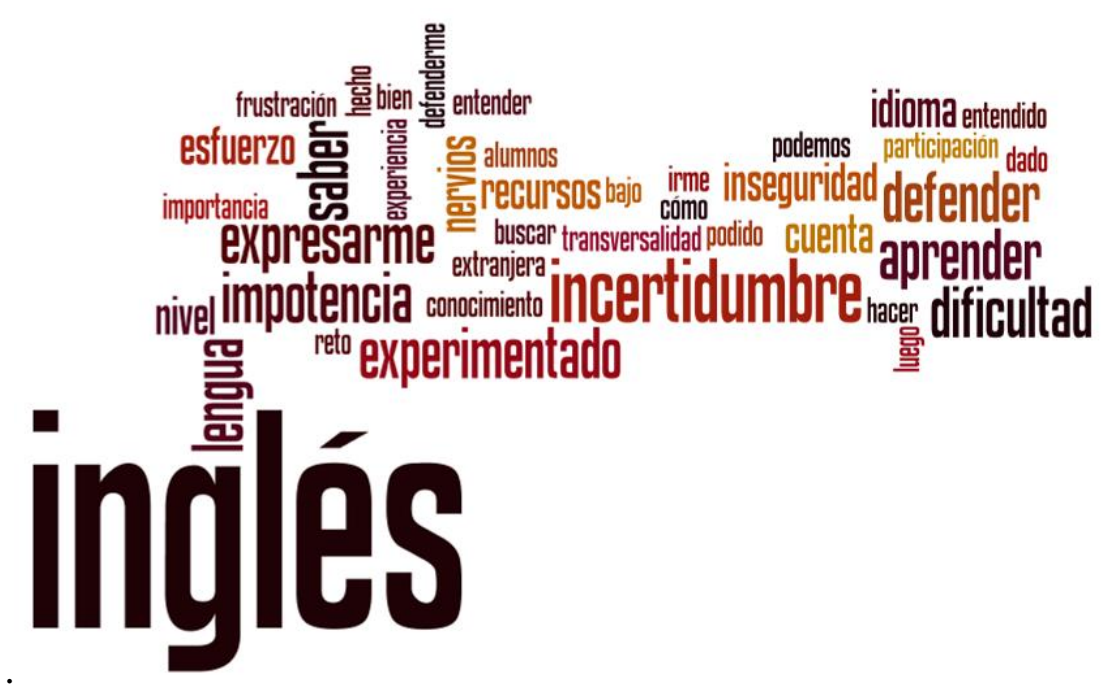

Figure 2 - Word frequency diagram in the working groups proposals for school projects.

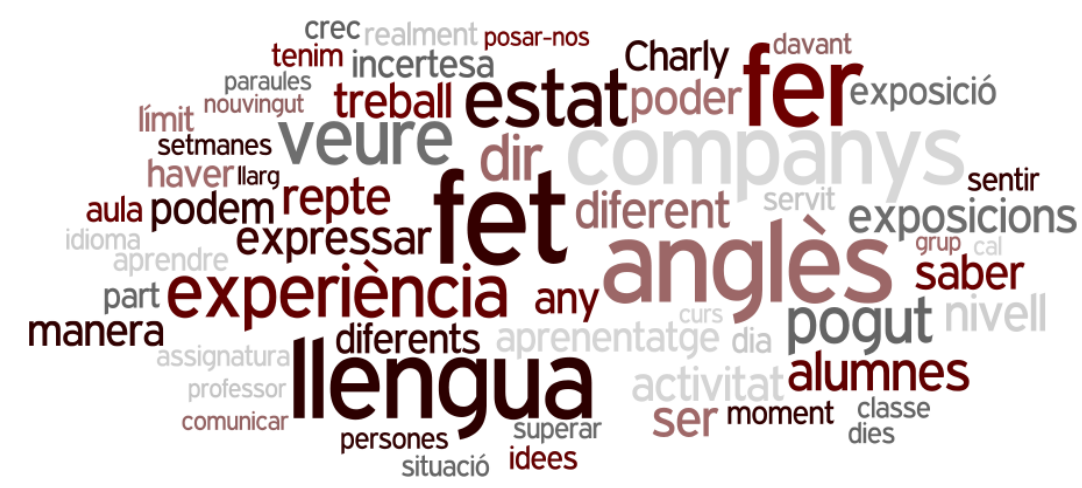


Figure 3 - Word frequency diagram of the comments in the Wiki by students.

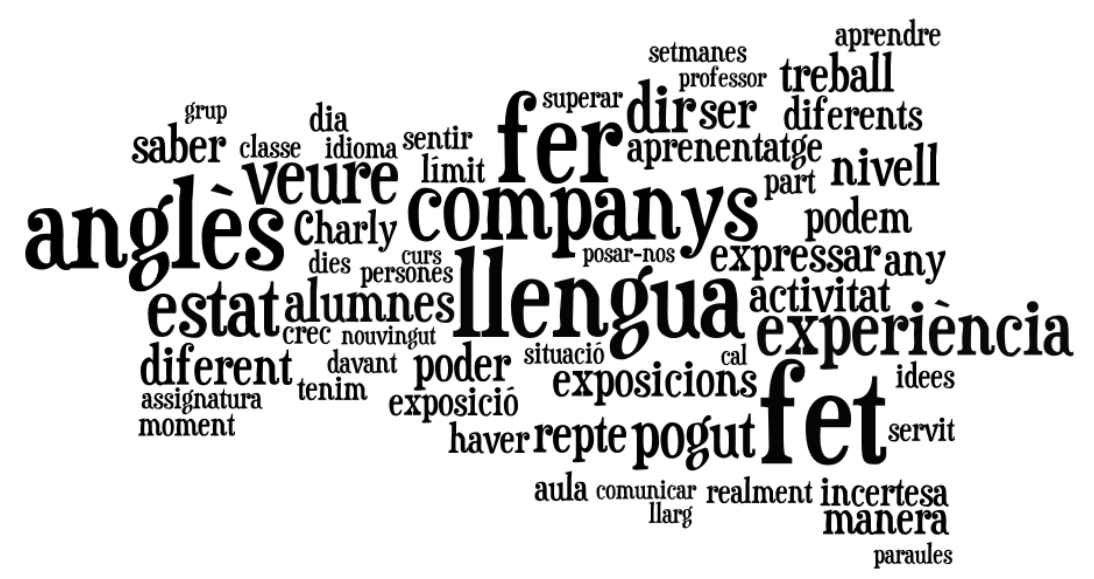

We see that words like uncertainty, difficulty, helplessness, frustration, insecurity.... have emerged in their "voices." The data show the interconnection between self, emotions and competence (See Tables 1 and 2). Initially in the activities, concerns were focused on finding the words to express the ideas and knowledge they believed to have built. Therefore, their main source for concern was the language. They prepared their presentations with technological support and then presented them. What happened when someone asked them about scientific content or to clarify ideas? There was "silence", "lots of silence", "a long, long silence." They could have looked for the words to communicate what they were being asked, and they would have probably found them. The responses they gave suggested they did not have the scientific understanding, at least not in English. The teaching team observed this aspect in many presentations; but in the debriefing session student voices referred to the impotence and frustration born from having the thoughts and ideas, but not the words to express them (due to the language barrier). Students did not refer to impotency or frustration through not knowing what to say due to a lack of knowledge; they could not "talk science". The focus was on the mode of communication, English as an additional language, rather than the content. The barrier of the mode of communication hid issues about the content of communication. One student raised the question in terms of a general incompetence:

"Besides feeling powerless, you feel incompetent. Will I be able to do my job well as a schoolteacher? ", Anabel asked herself.

Other words like effort, learning, difficulty, competence, express myself ... were part of comments that referred to self improvement. While the activity was being developed we saw which of our students grew in the face of difficulty and which had abandoned the task. This aspect is very important if we consider the need for future schoolteachers to be people and professionals who grow when faced with the difficulties and challenges that emerge in twenty-first century classrooms and schools. 
"Like most of us, I've been limited when expressing myself ... due to my lack of resources and communication skills in English. However I think this experience has motivated me, because I want to improve my English "said Frank.

We complemented this data with that obtained from the participation in the Wiki and the written assignments that were subsequently submitted, as shown in Figure 2 and 3. Again the focus is on the mode of communication and its associated feelings rather than the content.

The "voices" that emerged from this data reinforced the importance of the activity to put oneself in the position of the people who do not speak the common learning language; that is, this has been an exercise of "otherness" to understand better the boys and girls whose mother tongue is different to the common learning language of school. The students have lived it as an "experience", where language, and in this case English, has played a major role. We see the importance of feelings and the ability to communicate ideas and themselves. We now turn to what students say they are intending to do as a consequence of living the experience.

As can be seen in the three figures, "communication", "language" and "English" have high frequency, unlike the strength of the word "sciences" and the theme of the "R+R+R" projects; these do not appear. When students wrote and reflected on the activity, they started from their initial concern: the difficulty of presenting their work in English. In the comments made during the debriefing session we observed they had reflected on the activity done, without making any specific reference to the learning situations or the contents generated during the presentations; they had lived and prepared it like a performance. However, when they reflected on their experiences, the comments made in the written assignments and on the "Wiki" demonstrate they had reflected, not only about the activity, but propose future action, showing great strength to commit to their education as teachers, and in particular, to be able to deal with the multi-linguistic and multicultural heterogeneity in schools. This can be seen in the following comments:

"Having worked for two weeks in a language that is not my native tongue, I've realised the importance of welcoming children who reach a learning context in which the teaching language is not their own ", Rous said.

"This experience has helped us understand that when a new student whose mother tongue is not ours comes to school, he or she needs time to understand and to express him or herself", stated Judith.

"I've been able to experience first hand the feeling that arises when you want to express something and you can't think of the words. This same feeling is experienced by students who come to school with other native languages", commented Aina.

To complement the remarks on the Wiki and in the written assignments, the word "classmates" and "presentations" emerged with strength to support the learning process:

"We've learned to work as a group, that is, to unite with the group because for many people English was a challenge, and we've all helped each other; as an anecdote we'd 
just like to say that to encourage learning as a group which is part of a collective,

we've distributed all of the presentations to all of the groups"(group 1).

Less frequently raised was the question of learning subjects in English, that is, in CLIL contexts:

"Thinking in a foreign language is complicated and this is why giving subjects in other languages is complicated" (group 2).

"This is a way of building skills in an interdisciplinary way: for example, combining Science and English" (group 3).

\section{CONCLUSIONS}

Even though it was an activity based on a transdisciplinary perspective, the fact that it has been approached from the point of view of one subject in the primary teacher education syllabus has not helped the students live the educational situations from a transdisciplinary point of view. Although the guest lecturer was a Professor of Science Education, in the different data sets there are many references to the pedagogical subjects in which the activity was set and few to sciences which was the intended thematic backbone of their projects. English language has been often cited, but not scientific language. Does the same occur with other proposals made in CLIL contexts? It seems to be a good way to develop English in context but less appropriate for developing science education in this context.

When we do activities based on transdisciplinarity in the context of a subject, when we analyse the students' voices regarding the experiences, life lessons and knowledge they have developed around it, they "shout" their need to work together and make joint proposals across different subjects. As Darling-Hammond and Bransford (2005) say, teacher education continues to offer a fragmentary and inconsistent approach to curriculum and pedagogy. All of the students' voices greatly appreciated the activity and stated the importance of living it, even though they are not accustomed to doing so.

Josep M said: "throughout my schooling I've never received an English class outside the English language classroom."

Héctor commented: "this is the first time we've used English in a functional way."

Although this experience did not encourage "talking science" in English, it benefited the implementation and development of the students' English in a real context. If we live in multilingual societies we need multilingual people, and even more so teachers; Maturana (2010) states, we are the future. Depending on what we demonstrate in our lifestyles we show others which lifestyles are possible.

Based on Johnstone and Selepeng (2001) we were looking for a place where teachers and students could share meanings in order to debate, discuss, speak and write about science 
as a powerful strategy for developing thinking. However, as shown in Figure 2, helplessness, frustration, uncertainty, silence and a lack of confidence to express ourselves have emerged from the experiences. We need to explore other ways to support talking science in other languages.

These future schoolteachers have finished their second year of studies; next term they will have subjects from different curricular areas which should allow them to learn and improve in different languages. They will have to make decisions, read, document themselves, learn, share and deal with proposals designed, developed and researched in a CLIL context. This experience has undoubtedly helped them see something of the complexity of the relationship between teaching and learning. In their projects, students identified the importance of their activity, teamwork, experience and otherness. Now we need to develop tools and strategies that enable them to debate, discus, speak and write science. In the next iteration of the course, the outcomes of student projects will be in the form a workshop which includes activities rather than through a presentation. This small group work should be a better model of teaching and learning in an additional language. We aim to see the effects of this change in the learning outcomes for the student participants and the tutors.

Our aim of stimulating reflection on learning and teaching practices, and those within CLIL, seems to have been achieved. The value of encouraging peer interaction and giving time and space for reflection is shown by the data sets. Material from the wiki showed there was an exchange of ideas and analysis between peers, something that is known to be a fruitful way to develop thinking and opinions (Rhodes and Sawyer 2015). The assignment for the subject required students to reflect on their learning experiences as a way to support learning and as an expectation of being a teacher (Bolton 2010). These two data sets show a more reflective approach than the Nominal Group Technique data gathered immediately after the experience of the three weeks of working in English. We need to continue to ensure that we give such space and time and that we value reflection. It also shows the value of evaluation other than immediately after the events.

A focus group a year later shows that thanks to this activity, some of our students through group dynamics and personal development have taken charge of their learning. They have taken flight; they glide like storks over their studies.

"I've experienced that anything's possible with hard work and persistence."

"I don't remember my mark. It's not important. Obviously, that I passed is, obviously. I've a new way of looking at the world."

"I did it for me. I put what I wanted to put in my [assignment], not what I thought Gloria might want. We were told some connections to make with incidents and the curriculum. But I did what I wanted. I really enjoyed it, though it was a lot of work, overcoming challenges."

"It's a moment in your life when you become aware of what before you were unaware of, and you carry on learning. It's a process that never ends." 


\section{REFERENCES}

BOLTON, Gillie. Reflective practice: writing and professional development. London: Sage, 2010.

CAAMAÑO Aureli. Argumentar en ciencias. Alambique, n. 63, p. 5-10, 2010.

Disponível em: < http://dialnet.unirioja.es/servlet/articulo?codigo=3122016>. Acesso em: 22 jul. 2015.

COYLE, David. Developing CLIL: towards a theory of practice. In: FIGUERAS, N. (Ed.):

CLIL in Catalonia, from theory to practice. Barcelona. APAC, Monograph 6, p. 5-29, 2006.

COYLE, David. Content and language integrated learning: towards a connected research agenda for CLIL pedagogies. International Journal of Bilingual Education and Bilingualism, v.10, n.5, p. 543-562, 2007.

DARLING-HAMMOND, Linda; BRANSFORD, John. Preparing teachers for a changing world: what teachers should learn and be able to do. San Francisco: John Wiley \& Sons, 2005.

DELBECQ André; VAN DE VEN, Andrew; GUSTAFSON David. Group techniques for programme planning: a guide to nominal group and Delphi processes. Glenview Illinois: Scott Foreman and Company, 1975.

ESCOBAR, Cristina (Ed.); NUSSBAUM, Luci (Ed.). Aprendre en una altra llengua / Learning through another language / Aprender en otra lengua. Barcelona: Universidad Autonoma de Barcedlona, 2011.

EURYDICE. The Information Network on Education in Europe. Content and language integrated learning (CLIL) at school in Europe. Brusselas: European Commission, 2006. ISBN 92-79-00580-4.

FENSHAM, Peter. Science education policy-making: eleven emerging issues. Paris. UNESCO, 2008

HODSON, Derek. Teaching and learning about science: language, theories, methods, history, traditions and values. Rotterdam: Sense, 2009.

JOHNSTONE, Alex; SELEPENG, D. A language problem revisited. Chemistry Education: Research and Practice in Europe, v.2, n.1, p. 19-29, 2001.

JOVÉ MONCLÚS, Gloria; BETRIÁN VILLAS, Ester. Entretejiendo encajes entre la Universidad, los centros de arte y las escuelas. Arte, Individuo y Sociedad, v.24, n.2, p.301$314,2012$.

LASAGABASTER, David; ZAROBE, Yolanda Ruiz de. CLIL in Spain: implementation, results and teacher training. Cambridge: Cambridge Scholars, 2010. 
LEMKE, Jay L. Talking science: language, learning and values. Norwood, NJ: Ablex, 1990.

MATURANA ROMESÍN, Humberto. Discurso doctor honoris causa por la por la Universidad de Málaga, 9 de noviembre, 2010. Málaga, Revista Interuniversitaria de Formacion del Profesorado, v.74, n.26, p.189-203, 2012.

MEHISTO, Peeter; FRIGOLS, Maria Jesus. Uncovering CLIL: content and language integrated learning in bilingual and multilingual education. Oxford: Macmillan Books for Teachers, 2008.

MORIN, Edgar. On complexity. Cresskill, N.J.: Hampton, 2008.

NAVES, T.; VICTORI, M. CLIL in Catalonia: an overview of research studies. In.: LASAGABASTER, David (Ed.); ZAROBE, Yolanda Ruiz de (Ed.). CLIL in Spain: implementation, results and teacher training. Cambridge: Cambridge Scholars, 2010. p. 3054.

RHODES, Holly (Ed.); SAWYER, Keegan (Ed.). Public Engagement on Genetically Modified Organisms: when science and citizens connect - a Workshop Summary. Washington, D.C.: The National Academies Press, 2015.

WILKINS, Stephen; URBANOVIČ, Jolanta. English as the Lingua Franca in Transnational Higher Education: motives and prospects of institutions that teach in languages other than english. Journal of Studies in International Education, v.18, p-405-425, nov. 2014.

\section{Como citar este documento:}

MONCLUS, Gloria Jové; RYAN, Charly; VILLAS, Esther Betrián. Developing reflective primary teachers: talking science and speaking English as an additional language. ETD - Educação Temática Digital, Campinas, SP, v. 17, n. 2, p. 328-340, ago. 2015. ISSN 1676-2592. Disponível em: <http://periodicos.sbu.unicamp.br/ojs/index.php/etd/article/view/8638895>. Acesso em: 28 ago. 2015. 